\begin{tabular}{cc}
\hline UNIVERSITAS AHMAD DAHLAN \\
JURNAL BIOEDUKATIKA \\
\end{tabular}

\title{
Analisis kemampuan berpikir ilmiah siswa kelas XI IPA kawasan pegunungan Provinsi Daerah Istimewa Yogyakarta
}

\author{
Aisyah Ferra Anggraini a, 1, *, Maridi b, 2, Suciati b, 3 \\ a Magister Pendidikan Sains, Pascasarjana, Universitas Sebelas Maret, J1 Ir. Sutami 36A Kentingan, Surakarta 57126, Indonesia \\ b Pendidikan Biologi, Fakultas Keguruan dan Ilmu Pendidikan, Universitas Sebelas Maret, J1 Ir. Sutami 36A Kentingan, Surakarta 57126, \\ Indonesia \\ 1.ichaferra@yahoo.com; ${ }^{2}$ maridi_uns@yahoo.co.id; ${ }^{3}$ suciatisudarisman@staff.uns.ac.id \\ *korespondensi penulis
}

\begin{tabular}{ll}
\hline Informasi artikel & \\
\hline Sejarah artikel: & \\
Diterima & 21 Agustus 2018 \\
Revisi & 8 November 2018 \\
Dipublikasikan & 2 Desember 2018 \\
\hline
\end{tabular}

Kata kunci:

Kemampuan berpikir ilmiah

Pegunungan DIY

Topografi daerah

\section{ABSTRAK}

Penelitian ini bertujuan untuk menganalisis berpikir ilmiah siswa SMA Negeri kelas XI IPA di kawasan pegunungan Daerah Istimewa Yogyakarta (DIY). Jenis penelitian adalah deskriptif kualitatif. Pengumpulan data dilakukan menggunakan tes kemampuan berpikir ilmiah yang terdiri dari 25 item soal yang mengandung aspek berpikir ilmiah yaitu: (1) inquiry; (2) analisis; (3) inferensi; dan (4) argumentasi dan pengambilan data lainnya dengan wawancara. Penelitian dilakukan di SMA Negeri 1 Pakem dan SMA Negeri 1 Girimulyo kelas XI IPA kawasan pegunungan Daerah Istimewa Yogyakarta. Keseluruhan jumlah populasi yaitu 280 siswa dengan jumlah sampel 78 siswa. Pemilihan sampel menggunakan metode cluster random sampling. Data yang diperoleh selanjutnya diuji menggunakan statistik deskriptif kualitatif. Hasil penelitian menunjukkan perolehan pada masing-masing aspek yaitu: (1) inquiry: $43 \%$; (2) analisis: $44 \%$; (3) inferensi: $42 \%$; dan (5) argumentasi: $55 \%$. Hasil persentase menunjukkan bahwa kemampuan berpikir ilmiah masih kurang optimal karena rata-rata perolehan masih di bawah 50\%. Hal ini disebabkan sebagian besar kemampuan berpikir ilmiah siswa di kawasan pegunungan DIY masih kurang dioptimalkan. Daerah pegunungan merupakan faktor yang berpengaruh langsung terhadap kemampuan berpikir ilmiah siswa.

Key word:

DIY mountains

Regional topography

Scientific thinking ability

\begin{abstract}
Scientific thingking skill analyze of students' XI IPA at mountainous region of Daerah Istimewa Yogyakarta. This study aims to analyze the scientific thinking of students of the eleventh grade of science class high school in the mountainous areas of Special Region of Yogyakarta (DIY). This type of research is qualitative descriptive. Data collection was carried out using a scientific thinking ability test consisting of 25 items containing scientific thinking aspects: (1) inquiry; (2) analysis; (3) inference; and (4) argumentation and other data collection by interview. The research was conducted at SMA Negeri 1 Pakem and SMA Negeri 1 Giriulyo in 11th grade of science class in the mountainous areas of Special Region of Yogyakarta. The total population is 280 students with a total sample of 78 students. Sample selection using cluster random sampling method. The data obtained are then tested using descriptive qualitative statistics. The results of the study show that the acquisition of each aspect: (1) inquiry: 43\%; (2) analysis: 44\%; (3) inference: 42\%; and (5) argumentation: $55 \%$. The percentage results indicate that the scientific thinking ability is still less than optimal because the average acquisition is still below 50\%. This is because most of the scientific thinking abilities of students in the DIY mountainous areas are still not optimized. Mountainous areas are factors that directly influence the ability of students to think scientifically.
\end{abstract}

Copyright (C) 2018 Universitas Ahmad Dahlan 


\section{Pendahuluan}

Pendidikan merupakan proses yang didalamnya memiliki pengetahuan, keterampilan, dan secara efektif dapat mengembangkan sikap akademis kepada siswa (Rock et al., 2016). Perkembangan pendidikan harus sejalan dengan ketentuan yang bersifat mendasar untuk perkembangan ilmu pengetahuan (Aninda \& Suryadarma, 2017). Paradigma pendidikan yang ada di Indonesia mengalami pergeseran seiring dengan tuntutan zaman (Juliyanto, 2017). Abad ke-21 menuntut adanya pendidikan yang komprehensif dan kohesif sehingga prosesnya dapat fokus pada pengetahuan yang dapat diaplikasikan pada dunia nyata (Johnson, 2015; Rock et al., 2016). Pada dasarnya pendidikan di Indonesia mengalami perubahan dari pembelajaran verbalisme menuju ketrampilan aplikatif (Permendikbud Nomor 22 Tahun 2016). Tahap pengaplikasiannya perlu menginspirasi siswa untuk menjadi pemikir yang kreatif dalam pemecahan masalah terutama dalam bidang sains yang merujuk pada pembelajaran Biologi. Pembelajaran biologi diposisikan sebagai kegiatan ilmiah yang dapat menyelidiki, menginvestigasi, dan mengonstruksi pengetahuan sains (Aninda \& Suryadarma, 2017). Pembelajaran Biologi dalam praktiknya tidak boleh jauh dari kegiatan ilmiah guna membangun pengetahuan dalam bidang sains. Pengetahuan sains digunakan dalam sebuah kepastian dan perilaku yang baik dalam kehidupan (Ruprecht, 2008). Sains dianggap sebagai proses konstruksi yang menghendaki partisipasi aktif siswa (Dahar, 2011). Sains mendorong siswa untuk melakukan kegiatan pembelajaran yang mengarah ke metode ilmiah. Siswa diharuskan dapat mendorong pemikirannya agar lebih kritis dalam mengolah suatu permasalahan (Aditomo, Goodyear, Bliuc, \& Ellis, 2013). Selain itu siswa mulai dapat mencari pengetahuan baru dan berpikir pada tahap tingkat tinggi (Thitima \& Sumalee, 2012). Salah satu dalam mendorong berpikir tingkat tinggi siswa yaitu dengan berpikir ilmiah (Fatonah \& Prasetyo, 2014).

Kemampuan berpikir ilmiah dibutuhkan dalam menjawab tantangan pendidikan di masa kini terutama pada perkembangan sains (Nnorom, 2013). Berpikir ilmiah didefinisikan sebagai penalaran induktif dan deduktif untuk mencari sebuah jawaban pada proses ilmiah (Thitima \& Sumalee, 2012). Penalaran induktif digunakan dalam studi ilmiah yang dilakukan oleh seseorang seperti ilmuwan (Akinoglu \& Eren, 2015). Berpikir ilmiah juga terkait dalam permasalahan kehidupan sehari-hari (Varma, 2014). Proses dalam berpikir ilmiah difokuskan pada pengujian hipotesis, pengujian data secara sistematis dan menafsirkan data yang berhubungan dengan hipotesis (Koerber, Mayer, Osterhaus, Schwippert, \&
Sodian, 2015). Sependapat dengan Koerber, menurut Morris, Croker, Masnick, \& Zimmerman (2012) berpikir ilmiah berkaitan dengan kemampuan siswa dalam melakukan kegiatan ilmiah yang melibatkan kemampuan siswa dalam mengevaluasi hipotesis, data, dan proses dalam sebuah percobaan. Nilai strategis berpikir ilmiah yaitu dapat membangun pemikiran siswa dalam berpikir tingkat tinggi dan mampu memahamkan siswa terhadap kegiatan sains (Nnorom, 2013). Berpikir ilmiah erat kaitannya dengan berpikir tingkat tinggi, sehingga perlu mengoptimalkan kegiatan yang mengarah ke kegiatan ilmiah.

Terdapat empat aspek berpikir ilmiah yaitu: (1) inquiry; (2) analisis; (3) inferensi; dan (4) argumentasi (Kuhn, 2010). Keempat aspek tersebut menjadi sebuah bentuk penalaran yang logis dalam paradigma ilmiah (Kagee, Allie, \& Lesch, 2010). Selama ini kemampuan berpikir ilmiah kurang begitu banyak diterapkan dalam pembelajaran di sekolah terlihat dari perolehan skor hasil penelitian sebelumnya yang sudah dilakukan di salah satu sekolah di daerah pegunungan Merapi yang cenderung rendah. Skor pada aspek inquiry berjumlah 101, aspek analisis berjumlah 88 , aspek inferensi berjumlah 125 , dan aspek argumentasi berjumlah 56 (Anggraini, Suciati, \& Maridi, 2018). Salah satu faktor yang mempengaruhi kemampuan berpikir ilmiah siswa adalah faktor lingkungan.

Faktor lingkungan yang berkaitan seperti lingkungan keluarga, lingkungan sekolah dan budaya dari daerah yang ditinggali siswa seperti faktor geografi (Deng, Wang, \& Zhao, 2016). Variasi budaya dan sumber informasi yang mudah diakses juga berkontribusi dalam perkembangan sikap dan perilaku siswa (Mulasari, Sukesi, \& Sulistyawati, 2017). Dari keseluruhan faktor, yang berperan dalam kemajuan siswa tidak lepas dari lingkungan sekolah. Berdasarkan Peraturan Menteri Negara untuk lingkungan hidup Meilinda, Prayitno, \& Karyanto (2017) mengatakan bahwa sekolah idealnya digunakan sebagai tempat untuk memperoleh berbagai ilmu pengetahuan dan berbagai norma serta etika yang mewujudkan terciptanya kesejahteraan hidup dan cita-cita pembangunan berkelanjutan. Lingkungan sekolah yang memadai memiliki pengaruh terhadap kondisi siswa. Tidak hanya di lingkungan sekolah, lingkungan keluarga juga memiliki pengaruh terhadap perkembangan kepribadian siswa (Deng et al,, 2016). Kondisi lingkungan yang banyak mempengaruhi perkembangan kepribadian siswa yaitu salah satunya pada letak geografis (Chetty, Hendren, Kline, \& Saez, 2014). Letak geografis menjadi salah satu faktor membentuk karakter suatu daerah. Kondisi geografis 
yang masih belum banyak diteliti dalam melihat kemampuan berpikir ilmiah yaitu pada daerah pegunungan di Provinsi Daerah Istimewa Yogyakarta (DIY).

Daerah Istimewa Yogyakarta merupakan wilayah yang dikelilingi oleh pegunungan. Di wilayah DIY terdapat pegunungan besar yaitu pegunungan Merapi dan pegunungan Menoreh berdasarkan ketinggian wilayah (Anggraini \& Suciati, 2018). Pegunungan tersebut menempati sekitar 23\% dari luas wilayah DIY. Pegunungan Merapi merupakan pegunungan yang terdapat di kabupaten Sleman dan memiliki ketinggian antara 500- $>1000 \mathrm{~m}$ dpl dengan luas wilayah 1.495 ha meliputi kecamatan Pakem, Cangkringan, dan Turi, selain itu daerah ini didominasi oleh tanah vulkanik.

Kecamatan pakem terletak pada koordinat 77.66708' ha dan 110.42011'. Lain halnya dengan pegunungan Merapi, pegunungan Menoreh merupakan pegunungan yang berada di kabupaten Kulon Progo yang memiliki ketinggian antara 500$1000 \mathrm{~m}$ dpl yang meliputi kecamatan Girimulyo, Nanggulan, Kalibawang, dan Samigaluh dengan luas wilayah 216,76 $\mathrm{km}^{2}$. Pegunungan yang terdapat di Kulon Progo dicirikan dengan kompleks gunung api purba yang tumbuh di atas batuan Paleogen. Kecamatan Girimulyo terletak pada koordinat $110^{\circ}$ $07^{\prime} 14,5^{\prime \prime}-110^{\circ} 11^{\prime} 36^{\prime \prime}$ BT dan $07^{\circ} 45^{\prime} 00^{\circ}-07^{\circ}$ 48' 15" LS (Buntoro, 2013). Kondisi geografis yang demikian menjadi salah satu faktor yang mempengaruhi kemampuan berpikir ilmiah siswa karena geografi mempengaruhi capaian pendidikan suatu wilayah (Hillman, 2016).

Pada wilayah tersebut masih belum terlihat adanya pemberdayaan kemampuan berpikir ilmiah siswa. Berdasarkan observasi di salah satu sekolah di kawasan pegunungan pemberdayaan kemampuan berpikir ilmiah siswa masih belum terlihat. Pemberdayaan kemampuan berpikir ilmiah dalam kegiatan pembelajaran kurang diberdayakan secara maksimal. Pemberdayaan kemampuan berpikir ilmiah siswa idealnya dilakukan melalui praktik-praktik eksperimental dimana proses berpikir ilmiah dapat dibangun (Zhong, 2014). Selain itu untuk mencapai tujuan pembelajaran yang baik memerlukan sebuah rancangan pembelajaran yang baik pula dalam meningkatkan hasil belajar siswa berdasarkan standar intelektual siswa (Nurkholis, Miarsyah, Indrayanti, 2018). Kemampuan siswa terhadap standar intelektual juga dipengaruhi oleh faktor sosial ekonomi dari pendidikan orang tua dan mobilitas di lingkungan keluarga (Rock et al., 2016).

Berdasarkan pemaparan tersebut, selanjutnya dilakukan analisis secara keseluruhan mengenai kemampuan berpikir ilmiah siswa di daerah pegunungan di Daerah Istimewa Yogyakarta (DIY). Hal ini juga memungkinkan peneliti untuk dapat memberdayakan kemampuan berpikir ilmiah siswa dalam rangka untuk memajukan siswa dalam proses sains pada pembelajaran Biologi.

\section{Metode}

Penelitian yang dilakukan merupakan penelitian dengan metode deskriptif kualitatif. Penelitian deskriptif digunakan dalam mengumpulkan data berdasarkan faktor-faktor yang mendukung obyek penelitian dan dilanjutkan dengan menganalisis faktor-faktor tersebut (Arikunto, 2010), sedangkan kualitatif dapat menghasilkan data secara deskriptif (Moleong, 2002). Penelitian deskriptif dilakukan guna melihat gambaran suatu keadaan yang akan diteliti dan kualitatif yang digunakan dalam mendeskripsikan kemampuan berpikir ilmiah.

Populasi penelitian yang digunakan dalam penelitian ini berjumlah 280 siswa di kelas XI IPA SMA Negeri di kawasan pegunungan Merapi dan Menoreh Provinsi Daerah Istimewa Yogyakarta (DIY). Teknik pengambilan sampel menggunakan metode cluster random sampling sehingga diperoleh sekolah sampel yaitu SMA Negeri 1 Pakem di kelas XI MIPA 1 yang terletak di kawasan pegunungan Merapi, serta SMA Negeri 1 Girimulyo di kelas XI IPA 1 dan XI IPA 2 yang terletak di kawasan pegunungan Menoreh. Jumlah sampel yang diperoleh yaitu 78 siswa.

Teknik pengumpulan data dengan menggunakan instrumen tes dan wawancara terhadap siswa dan guru pada mata pelajaran Biologi. Instrumen tes terdiri dari 25 item soal pilihan ganda kemampuan berpikir ilmiah yang didalamnya mengandung empat aspek berpikir ilmiah menurut Kuhn (2010) yaitu: (1) inquiry, (2) analisis; (3) inferensi; dan (4) argumentasi, sedangkan instrumen yang digunakan dalam wawancara berupa lembar pertanyaan yang diajukan terhadap guru dan siswa mengenai kemampuan berpikir ilmiah siswa. Instrumen kemampuan berpikir ilmiah telah melalui proses validasi, baik secara internal maupun eksternal. Data yang diperoleh berikutnya dilakukan perhitungan untuk mengetahui perolehan skor dari hasil kemampuan berpikir ilmiah siswa yang digolongkan dalam empat kategori yang digunakan oleh Wijayadi (2017) yaitu: (1) Post Formal, (2) Upper Formal, (3) Low Formal, dan (4) Concrete yang dapat dilihat pada Tabel 1. 
Tabel I. Tingkat kemampuan berpikir ilmiah

\begin{tabular}{cc}
\hline Skor & $\begin{array}{c}\text { Tingkat Kemampuan Berpikir } \\
\text { Ilmiah }\end{array}$ \\
\hline $20-25$ & Post formal \\
$15-19$ & Upper formal \\
$10-14$ & Low formal \\
$0-9$ & Concrete \\
\hline
\end{tabular}

Instrumen kemampuan berpikir ilmiah siswa didalamnya terdapat 13 indikator: (1) merumuskan tujuan; (2) mengidentifikasi hasil pengamatan isu/fenomena; (3) menjelaskan definisi hipotesis; (4) merumuskan masalah berdasarkan isu/fenomena; (5) membuat hipotesis; (6) menjalankan definisi hipotesis; (7) menalar hasil literature review; (8) merancang desain percobaan; (9) menyajikan data hasil percobaan; (10) menemukan konsep atau teori dari hasil pengamatan; (11) membuat kesimpulan; (12) mencocokkan kesimpulan dengan hipotesis; (13) menyelesaikan masalah dengan menggunakan teori hasil percobaan.

\section{Hasil dan pembahasan}

Hasil penelitian mendeskripsikan mengenai analisis kemampuan berpikir ilmiah di kawasan pegunungan provinsi Daerah Istimewa Yogyakarta (DIY). Data dikumpulkan melalui tes kemampuan berpikir ilmiah yang dilakukan di SMA Negeri di kawasan pegunungan DIY yang terdiri dari SMA Negeri 1 Pakem dan SMA Negeri 1 Girimulyo serta wawancara terhadap siswa dan guru pada mata pelajaran Biologi. Masing-masing sekolah tersebut terletak di daerah pegunungan Merapi dan pegunungan Menoreh. Hasil wawancara terhadap siswa menunjukkan bahwa pada pembelajaran Biologi masih kurang memberdayakan kemampuan berpikir ilmiah karena kegiatan ilmiah seperti praktikum masih sedikit diterapkan dan pembelajaran cenderung mengarah pada penyampaian informasi, sedangkan hasil wawancara terhadap guru menunjukkan bahwa pembelajaran terkadang masih berorientasi pada hasil akhir. Pada dasarnya pembelajaran Biologi dituntut dalam keterampilan penyelidikan untuk memberdayakan suatu prosedur ilmiah sehingga mendukung sebuah proses pembelajaran yang bermakna (Mitasari \& Prasetiyo, 2016). Selanjutnya instrumen yang digunakan dalam penelitian ini menggunakan soal pilihan ganda yang berjumlah 25 item soal yang mengandung empat aspek kemampuan berpikir ilmiah yaitu: (1) inquity, (2) analisis; (3) inferensi; dan (4) argumentasi. Instrumen dalam penelitian ini digunakan untuk mengamati variabel yang muncul di sebuah pembelajaran (Riastuti, 2015). Saat ini pembelajaran berfokus pada kegiatan ilmiah dimana siswa dapat berpikir kritis terhadap sebuah permasalahan sehingga siswa dapat mengamati permasalahan, menyusun hipotesis, merancang percobaan dan menarik kesimpulan (Mulyana, Rusdi, \& Vivanti, 2018). Berikut dipaparkan pada Tabel 2 di hasil penelitian tes kemampuan berpikir ilmiah yang sudah didapatkan dari sampel sekolah negeri di kawasan pegunungan.

Tabel 2. Persentase aspek kemampuan berpikir ilmiah

\begin{tabular}{cc}
\hline Aspek Berpikir Ilmiah & Persentase \\
\hline Inquiry & $43 \%$ \\
Analisis & $44 \%$ \\
Inferensi & $42 \%$ \\
Argumentasi & $55 \%$ \\
\hline
\end{tabular}

Hasil menunjukkan bahwa persentase pada keseluruhan aspek cenderung rendah karena hampir semua aspek menunjukkan persentase di bawah 50\% kecuali pada aspek argumentasi. Aspek inferensi cenderung lebih rendah dibandingkan dengan keseluruhan aspek lainnya, sedangkan aspek argumentasi merupakan aspek yang tertinggi dibandingkan dengan keempat aspek kemampuan berpikir ilmiah. Aspek argumentasi cenderung lebih tinggi dikarenakan siswa lebih mampu menyelesaikan suatu permasalahan dalam metode ilmiah menggunakan teori dari hasil percobaan (Anggraini et al., 2018). Siswa berargumentasi berdasarkan buktibukti empiris yang telah didapatnya. Pada dasarnya pengetahuan ilmiah didasarkan pada observasi, penyelidikan dan penalaran secara logis (Ahİ, 2017).

Aspek argumentasi berkaitan dengan keakuratan dari data siswa yang dapat dijadikan sebagai diskusi dalam proses sains (Thitima \& Sumalee, 2012). Diskusi merujuk pada pembelajaran yang menghadapkan siswa pada sebuah permasalahan (Mitasari \& Prasetiyo, 2016). Berbeda dengan aspek argumentasi, aspek inferensi justru berada pada aspek yang paling rendah dengan persentase $42 \%$. Aspek inferensi menjadi aspek terendah karena siswa masih belum dapat mengarahkan pemikiran mereka terhadap kesimpulan yang didapatkan. Menurut (Kuhn, 2010) aspek inferensi berkaitan dengan mencocokkan kesimpulan dan hipotesis. Hal ini berbanding lurus dengan aspek inquiry yang memiliki persentase terendah setelah aspek inferensi. Aspek inquity didalamnya terdapat indikator mengenai kemampuan siswa dalam merumuskan hipotesis. Indikator dalam aspek ini mengarahkan siswa dalam melakukan penyelidikan ilmiah. Pada dasarnya inferensi merupakan sebuah kegiatan untuk menyimpulkan suatu permasalahan dalam sebuah proses ilmiah setelah siswa melakukan proses penyelidikan dan analisis data (Thitima \& Sumalee, 2012). Perolehan hasil tes kemampuan berpikir ilmiah digolongkan dalam empat tingkat yaitu: (1) 
Post Formal, (2) Upper Formal, (3) Low Formal, dan (4) Concrete. Capaian skor kemampuan berpikir ilmiah siswa tersaji pada Tabel 3

Tabel 3. Capaian skor kemampuan berpikir ilmiah siswa

\begin{tabular}{cc}
\hline Interval & Frekuensi \\
\hline $20-25$ & 0 \\
$15-19$ & 9 \\
$10-14$ & 51 \\
$0-9$ & 18 \\
\hline
\end{tabular}

Tabel 3 menunjukkan bahwa dari keseluruhan jumlah sampel di sekolah kawasan pegunungan provinsi DIY terdapat 51 siswa menjawab soal kemampuan berpikir ilmiah sebanyak 15 sampai dengan 19 butir soal, sedangkan tidak ada siswa yang menjawab soal kemampuan berpikir ilmiah sebanyak 20 sampai dengan 25 butir soal. Siswa yang menjawab soal kemampuan berpikir ilmiah dengan interval menjawab benar 0 sampai dengan 9 masih tinggi. $\mathrm{Hal}$ ini dikarenakan siswa masih kurang memahami mengenai soal kemampuan berpikir ilmiah baik dari aspek inquiry, analisis, inferensi, dan argumentasi. Persentase capaian dari kemampuan berpikir ilmiah dapat dilihat pada Gambar 1.

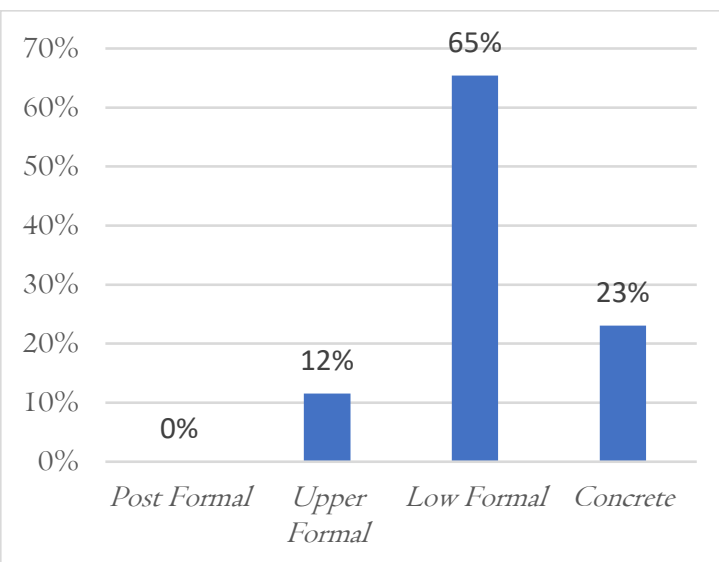

Gambar I. Persentase capaian kemampuan berpikir ilmiah siswa

Berdasarkan Gambar 1 dapat dilihat bahwa persentase tertinggi pada kategori low formal dengan persentase $65 \%$ diikuti dengan kategori concrete dengan persentase $23 \%$, upper formal dengan persentase $12 \%$, dan post formal dengan persentase $0 \%$. Hampir keseluruhan siswa pada sampel masih belum dapat menjawab soal-soal kemampuan berpikir ilmiah di atas 20. Hal ini berhubungan dengan perolehan keempat aspek kemampuan berpikir ilmiah dimana hampir keseluruhan aspek memperoleh persentase di bawah 50\% kecuali pada aspek argumentasi. Respons yang diberikan siswa terhadap soal kemampuan berpikir ilmiah juga cenderung merasa kesulitan dalam memahami soal tersebut.
Kesulitan dalam memahami soal kemampuan berpikir ilmiah dibuktikan dengan siswa yang masih belum dapat menjawab soal kemampuan berpikir ilmiah di atas 20 soal pilihan ganda. Analisis berikutnya yaitu membagi empat aspek kemampuan berpikir ilmiah ke dalam beberapa indikator.

Keempat aspek tersebut selanjutnya dijabarkan lagi ke dalam 13 indikator. Perolehan hasil 13 indikator dijelaskan pada Tabel 4.

Tabel 4. Perolehan skor indikator kemampuan berpikir ilmiah siswa

\begin{tabular}{|c|c|c|c|}
\hline $\begin{array}{c}\text { Aspek } \\
\text { Kemampuan } \\
\text { Berpikir } \\
\text { Ilmiah }\end{array}$ & Indikator & Jumlah & $\begin{array}{l}\text { Rata- } \\
\text { Rata }\end{array}$ \\
\hline \multirow[t]{6}{*}{ Inquiry } & Merumuskan tujuan & 42 & 14 \\
\hline & $\begin{array}{c}\text { Mengidentifikasi hasil } \\
\text { pengamatan } \\
\text { isu/fenomena }\end{array}$ & 37 & 12,3 \\
\hline & $\begin{array}{l}\text { Menjelaskan definisi } \\
\text { rumusan masalah }\end{array}$ & 35 & 11,6 \\
\hline & $\begin{array}{c}\text { Merumuskan masalah } \\
\text { berdasarkan } \\
\text { isu/fenomena }\end{array}$ & 31 & 10,3 \\
\hline & Membuat hipotesis & 50 & 16,6 \\
\hline & $\begin{array}{c}\text { Menjelaskan definisi } \\
\text { hipotesis }\end{array}$ & 82 & 27,3 \\
\hline \multirow[t]{3}{*}{ Analisis } & $\begin{array}{c}\text { Menalar hasil literature } \\
\text { review }\end{array}$ & 95 & 31,6 \\
\hline & $\begin{array}{l}\text { Merancang desain } \\
\text { percobaan }\end{array}$ & 57 & 19 \\
\hline & $\begin{array}{l}\text { Menyajikan data hasil } \\
\text { percobaan }\end{array}$ & 50 & 16,6 \\
\hline \multirow[t]{3}{*}{ Inferensi } & $\begin{array}{c}\text { Menemukan konsep } \\
\text { atau teori dari hasil } \\
\text { pengamatan }\end{array}$ & 108 & 36 \\
\hline & Membuat kesimpulan & 71 & 23,6 \\
\hline & $\begin{array}{c}\text { Mencocokkan } \\
\text { kesimpulan dengan } \\
\text { hipotesis }\end{array}$ & 83 & 27,6 \\
\hline Argumentasi & $\begin{array}{l}\text { Menyelesaikan masalah } \\
\text { dengan menggunakan } \\
\text { teori hasil percobaan }\end{array}$ & 129 & 43 \\
\hline
\end{tabular}

Tabel 4 menunjukkan jumlah keseluruhan hasil yang diperoleh dari sampel sekolah yang berada di kawasan pegunungan Merapi dan pegunungan Menoreh. Indikator ini menunjukkan penjabaran dari keempat aspek berpikir ilmiah. Indikator nomor 4 pada aspek inquiry berada di jumlah yang paling rendah dengan skor sebesar 31 dan rata-rata jumlah 10,3. Indikator tersebut berisi merumuskan masalah berdasarkan isu/fenomena. Berbeda halnya dengan persentase keseluruhan aspek, untuk aspek inferensi berada pada urutan terendah. Dilihat secara detail melalui indikator capaian pada masing-masing aspek, aspek inquiry berada di urutan ketiga dengan persentase sebesar $43 \%$ tetapi didalamnya terdapat 
satu indikator yang memiliki nilai lebih rendah dibandingkan dengan indikator yang lain. Aspek selanjutnya yang menempati aspek tertinggi yaitu aspek argumentasi dengan persentase capaian sebesar $55 \%$ dan indikator pada aspek ini memiliki jumlah skor tertinggi. Jumlah skor indikator pada aspek argumentasi sebesar 129 dengan rata-rata 43. Indikator tersebut berisi menyelesaikan masalah dengan menggunakan teori hasil percobaan. Capaian indikator dari sekolah daerah kawasan pegunungan di DIY yang dijadikan sampel tersaji pada Gambar 2.

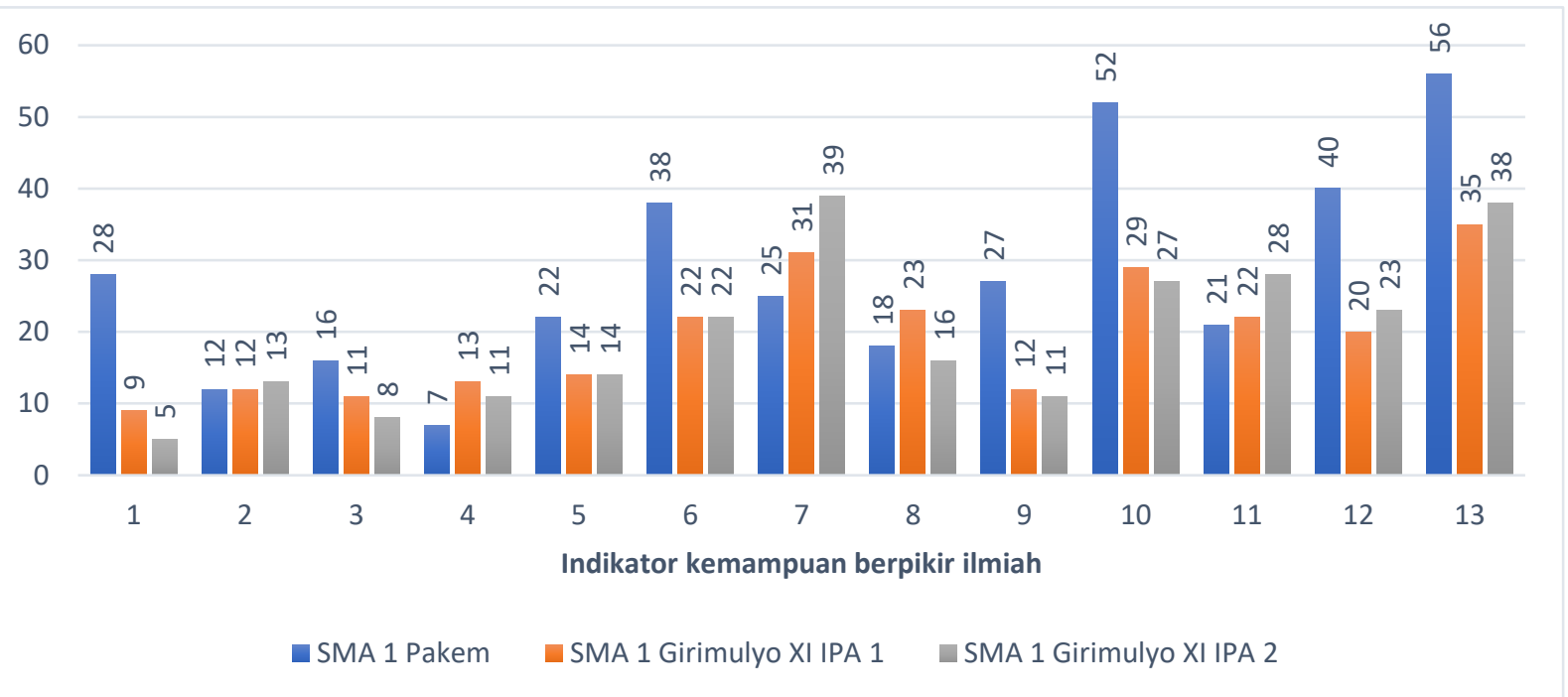

Gambar 2. Capaian indikator kemampuan berpikir ilmiah di sekolah daerah pegunungan di DIY

Gambar 2 menunjukkan bahwa masing-masing sekolah memiliki hasil skor berbeda-beda dalam pencapaian indikator kemampuan berpikir ilmiah. Keseluruhan indikator yang terendah terlihat pada indikator nomor 1 yang berisi merumuskan tujuan yang masuk ke dalam aspek inquiry. Aspek inquiry menjadi aspek yang menempati urutan ketiga karena kebanyakan siswa kelas XI IPA 2 di SMA Negeri 1 Girimulyo terlihat masih kurang terampil dalam merumuskan tujuan. Faktor penyebab rendahnya keterampilan siswa dalam merumuskan tujuan karena belum maksimalnya siswa dalam memperoleh pengetahuan mengenai kemampuan berpikir ilmiah dalam proses inquiry. Menurut Kremer, Specht, Urhahne, \& Mayer (2014) suatu penyelidikan ilmiah memiliki empat keterampilan yaitu merumuskan pertanyaan, membuat hipotesis, merancang percobaan untuk mengembangkan cara menemukan solusi, dan menafsirkan data. Keterampilan tersebut harus berjalan secara berurutan agar indikator dalam aspek inquity meningkat.

Pada dasarnya inquiry mendorong siswa untuk terlibat aktif dalam sebuah pembelajaran melalui proses penyelidikan (Eysink, Gersen, \& Gijlers, 2015). Keingintahuan siswa terhadap proses penyelidikan merupakan fitur alami dari manusia dan mampu merangsang keingintahuan siswa (Ruprecht, 2008). Inquiry merupakan kegiatan yang menggunakan kemampuan berpikir dalam memecahkan berbagai permasalahan, mempelajari gagasan, dan menerapkan gagasan yang dipelajari (Puspaningtyas \& Suparno, 2017). Menurut Lawson (2000) pembelajaran sains yang merujuk pada pembelajaran Biologi menuntut siswa untuk lebih sadar dalam proses belajar sehingga mampu untuk meningkatkan kemampuan secara umum dalam berpikir ilmiah. Berpikir menjadi sebuah proses kognitif untuk memperoleh sebuah pengetahuan (Husamah, Fatmawati, \& Setyawan, 2017). Akan tetapi berdasarkan hasil penelitian di dua sekolah di daerah pegunungan tersebut didapatkan bahwa aspek inferensi justru memiliki persentase terendah dibandingkan dengan aspek inquiry, analisis dan argumentasi.

Aspek inferensi mendapatkan persentase keseluruhan sebesar $42 \%$ yang hanya selisih $1 \%$ dengan aspek inquiry. Aspek inferensi memiliki tiga indikator capaian yaitu menemukan konsep atau teori dari hasil pengamatan, membuat kesimpulan, dan mencocokkan kesimpulan dengan hipotesis. Masingmasing jumlah skor yaitu 108, 71, dan 83. Aspek ini masuk ke dalam persentase rendah hal ini dikarenakan siswa lebih cenderung bingung dalam membuat kesimpulan sebuah permasalahan dengan permasalahan yang begitu kompleks dalam masingmasing pertanyaan. Selain itu siswa masih kurang terampil dalam mengambil pengertian, memahami, dan menafsirkan suatu permasalahan. Pada dasarnya aspek inferensi merupakan kegiatan dalam menyimpulkan sebuah data dari informasi yang sudah 
diperolehnya (Thitima \& Sumalee, 2012). Aspek pada urutan ke dua yaitu aspek analisis.

Aspek analisis memiliki perolehan persentase yang sama yaitu masing-masing $44 \%$. Kegiatan siswa pada aspek analisis terletak pada kegiatan membandingkan data dan bukti secara empiris (Thitima \& Sumalee, 2012). Indikator yang harus dipenuhi dalam pencapaian aspek antara lain menalar hasil literature review, merancang desain percobaan, dan menyajikan data hasil percobaan (Kuhn, 2010). Masing-masing indikator diperoleh rata-rata keseluruhan dari tiga sekolah yaitu 30, 24, dan 20,6. Siswa dikatakan dapat memberdayakan kemampuan berpikir ilmiah pada aspek analisis apabila ketiga indikator tersebut dapat tercapai, tetapi pada kenyataannya persentase yang didapatkan cenderung rendah karena masih berada di bawah 50\%. Siswa cenderung susah dalam menyajikan data percobaan karena siswa cenderung bingung dalam penyajian data pada hal praktik eksperimental yang mengarah ke berpikir ilmiah. Tetapi siswa cenderung lebih menguasai dalam menalar hasil literature review. Hal ini dikarenakan permasalahan yang disajikan mudah untuk dianalisis siswa dalam hal berpikir ilmiah. Aspek selanjutnya yang tertinggi diantara ketiga aspek lainnya yaitu pada aspek argumentasi.

Aspek argumentasi mengarahkan siswa pada kegiatan diskusi untuk mendapatkan alasan yang dapat diandalkan dari data yang sudah diperolehnya (Thitima \& Sumalee, 2012). Indikator pencapaian pada aspek argumentasi yaitu menyelesaikan masalah dengan menggunakan teori hasil percobaan dengan rata-rata skor capaian sebesar 43. Siswa cenderung mudah dalam menyelesaikan permasalahan apabila siswa memahami teori yang sudah didapatkan sehingga siswa dapat memiliki bekal dalam argumentasi mereka dan meningkatkan kemampuan berpikirnya. Indikator tersebut merupakan indikator tertinggi dari 12 indikator lainnya dan persentase perolehan di atas $50 \%$. Siswa mulai sedikit terarah dalam aspek ini karena teori yang sudah didapatkan dapat dijadikan sebagai dasar berargumen dengan tepat. Menurut Hornby (2000) bahwa kemampuan berpikir ilmiah digunakan dalam meningkatkan kemampuan berpikir siswa. Kemampuan yang didapatkan dari berpikir ilmiah yaitu siswa mampu membuat hipotesis, melakukan percobaan, interpretasi data dan memahami konsep sains (Koerber et al., 2015). Kegiatan yang berorientasi pada eksperimental dalam metode ilmiah menjadi sebuah sarana dalam mengembangkan kreativitas siswa (Mulyono, 2018). Pada dasarnya proses pembelajaran yang baik yaitu dengan menggabungkan proses ilmiah ke dalam kegiatan belajar untuk memperoleh ilmu pengetahuan (Stevens \& Witkow,
2014). Perlu adanya pembiasaan agar pembelajaran dapat membentuk suatu kemampuan tertentu (Setiono, Rustaman, Rahmat, \& Anggraeni, 2017). Terdapat beberapa faktor yang dapat mempengaruhi berpikir ilmiah salah satunya adalah faktor lingkungan.

Deng et al. (2016) menyatakan bahwa kemampuan berpikir ilmiah dipengaruhi oleh lingkungan sekolah, lingkungan keluarga, cara berpikir siswa, prestasi, dan budaya. Hubungan interpersonal keluarga dan demografi keluarga juga berperan dalam membentuk karakter siswa (Mulasari et al., 2017). Faktor lainnya yang mempengaruhi kemampuan berpikir ilmiah yaitu faktor lingkungan yang dilihat dari segi geografis. Geografi menjadi faktor dalam membentuk karakter suatu daerah (Chetty et al., 2014), geografis dapat mempengaruhi capaian pendidikan dari masyarakat yang berada disekitarnya (Hillman, 2016).

Provinsi DIY merupakan daerah yang dikelilingi oleh dua pegunungan besar yaitu pegunungan Merapi dan pegunungan Menoreh (Anggraini \& Suciati, 2018). Ketinggian di wilayah pegunungan DIY terletak pada ketinggian antara 100-499 m dpl, 500$999 \mathrm{~m}$ dpl, dan di atas $1000 \mathrm{~m}$ dpl (Pemerintah Daerah DIY, 2015). Masyarakat di kawasan pegunungan DIY sebagian besar memiliki pekerjaan dibidang peternakan, pertanian, dan pariwisata (Pratomo, 2006). Kondisi lingkungan masyarakat yang demikian menjadi faktor kurang optimalnya siswa dalam kemampuan berpikir ilmiah, selain itu kondisi sosial ekonomi dari pendidikan orang tua juga menjadi faktor yang mempengaruhi standar intelektual siswa (Rock et al., 2016). Menurut Hargreaves, Kvalsund, \& Galton (2009) proporsi pendidikan di masyarakat yang berada di daerah pedesaan masih tergolong prioritas nasional yang rendah. Hal ini karena masih kurangnya perhatian mengenai pendidikan di daerah pegunungan. Pendidikan dalam suatu wilayah juga dipengaruhi oleh beberapa faktor seperti lingkungan keluarga, lingkungan sekolah dan letak geografisnya (Deng et al., 2016). Daerah pegunungan Merapi dan Menoreh umumnya berada di lereng dan perbukitan. Konstruksi wilayah di daerah Merapi secara umum berada di lereng-lereng yang sebagian masyarakatnya berada di sosial ekonomi rendah, begitu juga di daerah pegunungan Menoreh. Orang tua siswa yang berada di kawasan pegunungan Merapi dan Menoreh cenderung menginginkan anaknya untuk bekerja sehingga kesadaran terhadap pendidikan masih rendah sehingga berdampak pada kemampuan berpikir ilmiah siswa (Rahmawanta, 2013). Pemberdayaan kemampuan berpikir ilmiah siswa idealnya dilakukan melalui praktik-praktik eksperimental yang dapat 
membangun kemampuan berpikir ilmiah siswa di sekolah-sekolah kawasan pegunungan.

Penelitian yang dilakukan oleh Sutrisno (2013) dalam (Bunu, 2014) yang menyatakan bahwa anak yang berorientasi pada pekerjaan cenderung memiliki prestasi belajar yang kurang optimal. Hal ini yang menjadi faktor penyebab bahwa kemampuan berpikir ilmiah di kawasan pegunungan DIY masih tergolong rendah. Dari penelitian ini maka diperlukan adanya model pembelajaran yang tepat dalam memberdayakan kemampuan berpikir ilmiah siswa melalui praktik-praktik eksperimental di daerah pegunungan provinsi DIY.

\section{Simpulan}

Berdasarkan hasil penelitian mengenai kemampuan berpikir ilmiah di kawasan pegunungan DIY didapatkan bahwa aspek inferensi memiliki persentase terendah dibandingkan dengan ketiga aspek berpikir ilmiah lainnya, sedangkan aspek argumentasi memiliki persentase tertinggi. Aspek inferensi mendapat persentase sebesar $42 \%$ sedangkan aspek argumentasi sebesar 55\%. Aspek argumentasi memiliki persentase tertinggi karena siswa cenderung dapat menyelesaikan sebuah permasalahan dengan menggunakan teori hasil percobaan. Berbeda halnya dengan aspek argumentasi, aspek inferensi memiliki persentase terendah tetapi indikator pada aspek inquiry yang berisi merumuskan masalah berdasarkan isu/fenomena juga berada di posisi terendah dengan jumlah 31 dengan rata-rata 10,3. Selain itu sebagian besar siswa hanya bisa menjawab soal kemampuan berpikir ilmiah antara 10-14 item soal pilihan ganda. Rendahnya kemampuan berpikir ilmiah dipengaruhi oleh salah satu faktor yaitu faktor lingkungan antara lain letak geografis, lingkungan sekolah, lingkungan keluarga, dan budaya. Faktor tersebut memiliki pengaruh langsung terhadap kemampuan berpikir ilmiah siswa karena tidak semua siswa berorientasi pada bidang pendidikan. Selain itu letak geografi juga mempengaruhi pendidikan di sekolah kawasan pegunungan.

\section{Ucapan terima kasih}

Penulis berterima kasih kepada Ibu Sri Budirahayu, Ibu Tutik Sunarti dan siswa-siswa kelas XI MIPA 1 di SMA Negeri 1 Pakem dan kelas XI IPA 1 dan 2 di SMA Negeri 1 Girimulyo Provinsi Daerah Istimewa Yogyakarta (DIY).

\section{Referensi}

Aditomo, A., Goodyear, P., Bliuc, A.-M., \& Ellis, R. A. (2013). Inquiry-based learning in higher education: principal forms, educational objectives, and disciplinary variations. Studies in Higher Education, 38(9), 1239-1258. https://doi.org/10.1080/03075079.2011.616 584

Ahİ, B. (2017). Thinking about digestive system in early childhood: A comparative study about biological knowledge. AHI, Cogent Education, 4, 1-16. https://doi.org/10.1080/2331186X.2017.12 78650

Akinoglu, O., \& Eren, C. D. (2015). Pre-service teachers' metaphors regarding the voncept of scientific thinking. The Anthropologist, 20(3), 476-484. https://doi.org/10.1080/09720073.2015.118 91752

Anggraini, A., \& Suciati, S. (2018). The influence of inquiry learning model with scaffolding on cognitive learning outcomes in biology subjects of eleventh grade of science class in special region of yogyakarta mountain areas. In Proceedings of the International Conference on Teacher Training and Education 2018 (ICTTE 2018) (hal. 28-34). Paris, France: Atlantis Press. https://doi.org/10.2991/ictte-18.2018.6

Anggraini, Suciati, \& Maridi. (2018). Identifikasi kemampuan berpikir ilmiah siswa kelas XI IPA di SMA Negeri 1 Turi, Sleman. In PROSIDING Seminar Nasional Pendidikan Fisika FITK UNSIQ (hal. 586-587). Diambil dari https://ojs.unsiq.ac.id/index.php/semnaspf/ar ticle/view/123/40

Aninda, B. O., \& Suryadarma, I. G. P. (2017). Penerapan PBL dengan suplemen komik digital terhadap kemampuan pemecahan masalah dan sikap peduli lingkungan. JURNAL BIOEDUKATIKA, 5(2), 46-53. https://doi.org/10.26555/ bioedukatika.v5i2.6499

Arikunto, S. (2010). Prosedur penelitian: Suatu pendekatan praktik. Jakarta: Rineka Cipta.

Buntoro, W. (2013). Pemetaan zona gerakan tanah di kecamatan girimulyo, kabupaten kulonprogo provinsi Daerah Istimewa Yogyakarta. Jurnal Ilmiah $M T G$, 6(2), 93-106. Diambil dari http://jurnal.upnyk.ac.id/index.php/mtg/articl e/view/260

Bunu, H. Y. (2014). Kesadaran masyarakat suku dayak terhadap pendidikan anak di pedalaman Kalimantan Tengah. Jurnal Cakrawala Pendidikan, 3(3), 445-453. https://doi.org/ 10.21831/cp.v3i3.2388

Chetty, R., Hendren, N., Kline, P., \& Saez, E. (2014). Where is the land of opportunity? The geography of intergenerational mobility in the united states. The Quarterly Journal of Economics, 129(4), 1553-1623. https:// doi.org/10.1093/qje/qju022

Dahar, R. W. (2011). Teori-teori belajar dan pembelajaran. Jakarta: Erlangga. 
Deng, L., Wang, L., \& Zhao, Y. (2016). How creativity was affected by environmental factors and individual characteristics: A cross-cultural comparison perspective. Creativity Research Journal, 28(3), 357-366. https://doi.org/ 10.1080/10400419.2016.1195615

Eysink, T. H. S., Gersen, L., \& Gijlers, H. (2015). Inquiry learning for gifted children. High Ability Studies, 26(1), 63-74. https://doi.org/10.1080/ 13598139.2015 .1038379

Fatonah, S., \& Prasetyo, Z. K. (2014). Pembelajaran sains. Yogyakarta: Ombak.

Hargreaves, L., Kvalsund, R., \& Galton, M. (2009). Reviews of research on rural schools and their communities in British and Nordic countries: Analytical perspectives and cultural meaning. International Journal of Educational Research, 48(2), 80-88. https://doi.org/10.1016/ j.ijer.2009.05.002

Hillman, N. W. (2016). Geography of college opportunity. American Educational Research Journal, 53(4), 987-1021. https://doi.org/ 10.3102/0002831216653204

Hornby, A. S. (2000). Oxford advanced learners of current english. New York: Oxford University Press.

Husamah, H., Fatmawati, D., \& Setyawan, D. (2017). Model pembelajaran OIDDE pada matakuliah pengetahuan lingkungan untuk meningkatkan keterampilan berpikir kritis mahasiswa calon guru biologi. JURNAL BIOEDUKATIKA, 5(2), 73-85. https://doi.org/10.26555/ bioedukatika.v5i2.7321

Johnson, K. (2015). Behavioral Education in the 21st Century. Journal of Organizational Behavior Management, 35(1-2), 135-150. https:// doi.org/10.1080/01608061.2015.1036152

Juliyanto, E. (2017). Model pembelajaran IPA dengan pendekatan inkuiri berbasis proyek untuk menumbuhkan kompetensi menyelesaikan masalah. Indonesian Journal of Science and Education, 1(1), 36-42. Diambil dari http://jurnal.untidar.ac.id/index.php/ijose/arti cle/view/419

Kagee, A., Allie, S., \& Lesch, A. (2010). Effect of a course in research methods on scientific thinking among psychology students. South African Journal of Psychology, 40(3), 272-281. https://doi.org/ 10.1177/008124631004000306

Koerber, S., Mayer, D., Osterhaus, C., Schwippert, K., \& Sodian, B. (2015). The development of scientific thinking in elementary school: A comprehensive inventory. Child Development, 86(1), 327-336. https://doi.org/10.1111/cdev.12298

Kremer, K., Specht, C., Urhahne, D., \& Mayer, J. (2014). The relationship in biology between the nature of science and scientific inquiry. Journal of Biological Education, 48(1), 1-8. https://doi.org/10.1080/00219266.2013.788 541

Kuhn, D. (2010). What is Scientific Thinking and How Does It Develop? In U. Goswami (Ed.), Blackwell Handbook of Childhood Cognitive Development (hal. 371-393). Malden, MA, USA: Blackwell Publishers Ltd. https://doi.org/10.1002/9780470996652.ch 17

Lawson, A. E. (2000). A learning cycle approach to introducing osmosis. The American Biology Teacher, 62(3), 189-196. https://doi.org/ $10.2307 / 4450871$

Meilinda, H., Prayitno, B. A., \& Karyanto, P. (2017). Student's environmental literacy profile Of adiwiyata green school in Surakarta, Indonesia. Journal of Education and Learning (EduLearn), 11(3), 299-306. https://doi.org/10.11591/ edulearn.v11i3.6433

Mitasari, Z., \& Prasetiyo, N. A. (2016). Penerapan model diskusi-presentasi dipadu analisis kritis artikel melalui lesson study untuk meningkatkan pemahaman konsep, kemampuan berpikir kritis, dan komunikasi. JURNAL BIOEDUKATIKA, 4(1), 11-14. https://doi.org/10.26555/ bioedukatika.v4i1.4736

Moleong, L. (2002). Metodologi penelitian kualitatif (3 ed.). Bandung: Remaja Rosdakarya.

Morris, B. J., Croker, S., Masnick, A. M., \& Zimmerman, C. (2012). The emergence of scientifc reasoning. In H. Kloos, B. Morris, \& J. Amaral (Ed.), Current Topics in Children'a Learning and Cognition (Vol. 53885). London: IntechOpen. Diambil dari https://www.intechopen.com/ books/current-topics-in-children-s-learningand-cognition

Mulasari, S. A., Sukesi, T. W., \& Sulistyawati, S. (2017). Teenager attitude in globalization era in senior high school in Yogyakarta. Journal of Education and Learning (EduLearn), 11(4), 358-367. https://doi.org/10.11591/edulearn.v11i4.582 0

Mulyana, S., Rusdi, R., \& Vivanti, D. (2018). The effect of guided inquiry learning model and scientific performance on student learning outcomes. Indonesian Journal of Science and Education, 2(1), 105-109. https://doi.org/10.31002/ ijose.v2i1.596

Mulyono, Y. (2018). Improving creativity of the future physics teachers through general biology learning based on CTL with experimental method. Indonesian Journal of Science and Education, 2(1), 62-68. https://doi.org/10.31002/ ijose.v2i1.621

Nnorom, N. R. (2013). The effect of reasoning skills on students achievement in biology in anambra state. 
International Journal of Scientifc \& Enginering Research, 4(12), 2102-2104.

Nurkholis, E., Miarsyah, M., \& Indrayanti, R. (2018). The influence of self-efficacy and learning independence againts the outcomes of the study material on ecosystem biology high school student of grade X. Indonesian Journal of Science and Education, 2(1), 75. https://doi.org /10.31002/ijose.v2i1.597

Pemerintah Daerah DIY. (2015). Rencana kerja pembangunan daerah Daerah Istimewa Yogyakarta 2016. Yogyakarta. Diambil dari https://www.bappenas.go.id/files/rpjmd_dan_ rkpd_provinsi/DI Yogyakarata/RKPD DI Yogyakarta 2016.pdf

Pratomo, I. (2006). Klasifikasi gunung api aktif Indonesia, studi kasus dari beberapa letusan gunung api dalam sejarah. Indonesian Journal on Geoscience, 1(4), 209-227. https://doi.org/10.17014/ ijog.vol1 no4.20065

Puspaningtyas, K., \& Suparno. (2017). Pengaruh penerapan model inquiry terbimbing terhadap kemampuan analisis dan keterampilan proses sains. Journal of Science and Education, 1(1), 8-16. Diambil dari http://jurnal.untidar.ac.id/index.php/ijose/arti cle/view/416

Rahmawanta, S. (2013). Bersama masyarakat membangun pendidikan. Jurnal Ilmu Pendidikan, 1(2), 12 15.

Riastuti, R. D. (2015). Penerapan pendekatan sains teknologi lingkungan masyarakat untuk meningkatkan aktivitas dan hasil belajar biologi di SMAN 1 Kota Padang. JURNAL BIOEDUKATIKA, 3(2), 30-38. https:// doi.org/10.26555/bioedukatika.v3i2.4152

Rock, M. L., Spooner, F., Nagro, S., Vasquez, E., Dunn, C., Leko, M., ... Jones, J. L. (2016). 21st century change drivers: Considerations for constructing transformative models of special education teacher development. Teacher Education and
Special Education: The Journal of the Teacher Education Division of the Council for Exceptional Children, 39(2), 98-120. https:// doi.org/10.1177/0888406416640634

Ruprecht, R. (2008). How to guarantee quality in education, 7, 107-118. Diambil dari http:/ / citeseerx.ist.psu.edu/viewdoc/download ?doi=10.1.1.447.7554\&rep=rep1\&type $=$ pdf

Setiono, S., Rustaman, N. Y., Rahmat, A., \& Anggraeni, S. (2017). Kemampuan mahasiswa calon guru biologi dalam menyusun scientific papers. JURNAL BIOEDUKATIKA, 5(2), 54-58. https://doi.org/10.26555/bioedukatika.v5i2.7 070

Stevens, C., \& Witkow, M. R. (2014). Training scientific thinking skills. Teaching of Psychology, 41(2), 115-121. https://doi.org/10.1177/00986283 14530341

Thitima, G., \& Sumalee, C. (2012). Scientific thinking of the learners learning with the knowledge construction model enhancing scientific thinking. Procedia - Social and Behavioral Sciences, 46(1999), 3771-3775. https:// doi.org/10.1016/j.sbspro.2012.06.144

Varma, K. (2014). Supporting scientific experimentation and reasoning in young elementary school students. Journal of Science Education and Technology, 23(3), 381-397. https://doi.org /10.1007/s10956-013-9470-8

Wijayadi, A. W. (2017). Pengaruh strategi pembelajaran dan kemampuan berpikir ilmiah terhadap hasil belajar kimia. EduChemia (Jurnal Kimia dan Pendidikan), 2(2), 151-160. https://doi.org/ 10.30870/educhemia.v2i2.1473

Zhong, G. (2014). Training of scientific thinking methods in teaching of inorganic and analytical chemistry. Journal of Chemical and Pharmaceutical Research, 6(7), 1503-1508. Diambil dari https://pdfs.semanticscholar.org/a3cb/c342ba eac89601da1ff740aOa5d4aOa4ca1c.pdf 